Click www.researchjournal.co.in/online/subdetail.html to purchase.

Volume 5 | Issue 2 | September, 2014 | 284-288 a ISSN-2231-6434 |

International Research Journal of Agricultural Economics and Statistics

Visit Us - www.researchjournal.co.in DOI : 10.15740/HAS/IRJAES/5.2/284-288

\title{
Research Paper An economic study of growth trend in area, production and productivity of garlic in U.P.
}

\section{J. RAI, DIWAKER NATH SHUKLA AND PRABHAKAR KUMAR}

See end of the paper for authors' affiliations

Correspondence to :

\section{J. RAI}

Department of Agricultural Economics and Statistics,

C.S. Azad University of Agriculture and Technology, KANPUR (U.P.) INDIA

Email:

jharakhande_9csauk@redifmail. com

\section{Paper History :}

Received : 08.05.2014;

Revised : 05.08.2014;

Accepted: 20.08 .2014
ABSTRACT : In the present study, an attempt has been made to know the trends in area, production and productivity of Garlic crop in different agro-economic regions of Uttar Pradesh for the period 1995-96 to 200910, The study data period has been divided into three periods viz., phase I, II and III. The estimation of growth rate was done by Compound Growth Rate method. It has been observed that the overall growth rate in area, production and productivity of Garlic in the State showed an increasing trend, which was recorded 16.17, 18.11 and 1.67 per cent per annum, respectively. The projected area under Garlic would be estimated around 91.848 thousand hectares, production 535.494 thousand tones and productivity 63.33 quintal per hectares, respectively for the 2020-21 A.D.

KEY WORDS : Garlic, Area, Production, Productivity, Growth trend, Projected growth rate

HOW TO CITE THIS PAPER : Rai, J., Shukla, Diwaker Nath and Kumar, Prabhakar (2014). An Economic Study of Growth Trend in area, production and productivity of garlic in U.P. Internat. Res. J. Agric. Eco. \& Stat., 5 (2) : 284-288. 